\title{
Perceptions of Rural Further Education and Training (FET) College Students Towards Placement at Small, Medium and Micro Enterprises (SMMES): The South African Rural Perspective
}

\author{
Matome Malale $^{1}$ \\ Lazarus Sentsho² \\ University of South Africa, Mangosuthu University of Technology \\ 1 malalmm@unisa.ac.za, ${ }^{2}$ sentsho@mut.ac.za
}

Doi:10.5901/mjss.2014.v5n20p683

\begin{abstract}
The provision of students with curriculum related practical experience during studies or after completion of studies is becoming a staple of the twenty-first century education. In the South African education system, various terms are used for this practice, such as experiential training, learnership, internship and Work Integrated Learning (WIL). Following the inception of FET colleges sector, a new term was coined, the Workplace Based Experience (WBE). It is distinguished by its flexibility as students are not required as is the common practice, to be placed at well-known private businesses or public institutions. Students can be placed at small businesses. Flexible as it is, FET colleges in rural areas where business is dominated by Small Medium and Micro Enterprises (SMMEs), students are averse to placement at these businesses. This paper explores the causes of these students' aversion of placement at SMMEs in order to come up with measures to change the perceptions and improve workplacement rate. Data was collected by means of a Researcher journal and Interviews with students at the two campuses of a rural FET college in the Limpopo Province of South Africa. The constant comparative method was used to analyse data.
\end{abstract}

Keywords: WBE, SMME, FET College, perceptions, students

\section{Introduction}

Since the inception of democracy in South Africa in 1994, the education system has been undergoing transformation. The FET sector emerged as a result of this transformation. South Africa's FET colleges are therefore relatively new in the education sector. As part of transformation, the new program, the National Certificate Vocational (NCV), was introduced with the intention of responding to the skills demand of the South African economy.

As the core function of the FET colleges is education and training for the world of work, it is the responsibility of the colleges to ensure that the students experience the workplace before their completion of studies. This was emphasized after the Department of Higher Education (DHET) had realized that lack of real work exposure is a great hindrance to access job opportunities (Mopani South East FET College, 2012:7). In his keynote address at the launch of quality council for trades and occupations, the Minister of Higher Education Blade Nzimande said:

"We know how that college training is, on its own not enough. If work training does not complement the learning done at colleges, we could well find that the young stars we work so hard to train remain unemployed after they qualify." (SSACI Swiss-South Africa Initiative, 2012:5).

In order to achieve this goal, the Department of Education engaged the Swiss-South Africa Initiative (SSACI) in a project to facilitate the workplace placement of FET college students. The main purpose of the project is to align the NCV program with the needs of the industry and foster sustainable college-industry partnership (SSACl, 2012: foreword). In conjunction with the Department of Higher Education, SSACI facilitates the placement of students with employers, which is aimed at 70\% target of placing students by 2014 (DHET, 2013:33).

In the rural areas where SMMEs (Small Medium and Micro Enterprises) dominate as job providers, colleges experience challenges of students who are averse to placement at SMMEs. WBE being new, the paper will define the concept, outline its features and importance, and come up with recommendations to change the students' perception in order to improve the students' placement rate. 


\section{Theoretical Perspective}

"Tell me; and I forget. Teach me; and I remember. Involve; me and I learn." Confucius, 450 B.C

This popular quotation explains the importance of learning by doing or the link between school life and working life or workplace experience. The basis of this type of learning is the experiential theory.

This research is therefore underpinned by Experiential Learning Theory. Although this theory can be traced back to the earlier work of John Dewey, Jean Piaget, Kurt Lewin and other authors and advocates of experiential learning, David Kolb the German psychologist, is regarded as the architect of this theory (Dochy, Gijbels, Segers and Van den Bosche, 2011: 55). In his definition, Kolb in Cherry (2014 [online]) regards learning as:

"the process whereby knowledge is created through the transformation of experience."

Kolb and his associate Fry developed The Experiential Learning Model. In this model, learning is composed of four elements (Tenant, 2006:87). The four elements are represented in a famous learning cycle as depicted in the figure below.

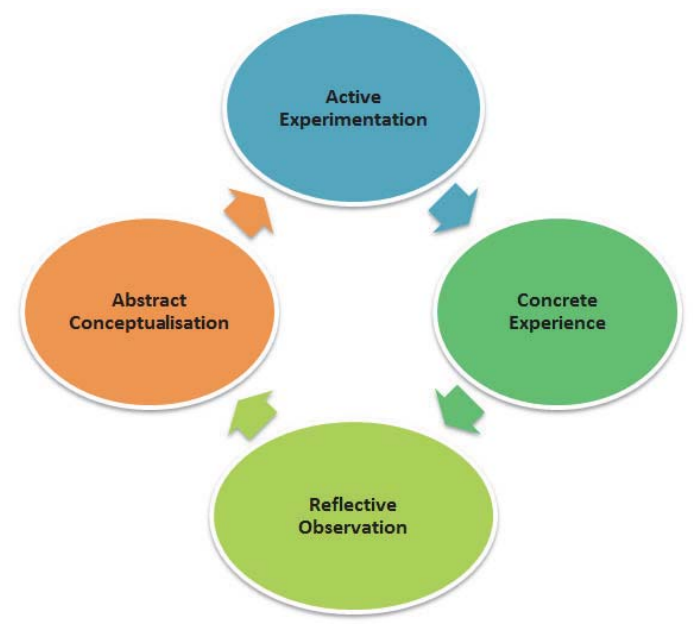

Figure 3.1 David Kolb’s Experiential Learning Cycle

The cycle involves concrete experience, followed by reflective observation, followed by abstract conceptualization (formulation of hypothesis or some kind of theory), followed by experimentation or testing in new situations. In order for learning to be effective, the educator should take the learner around each stage of the cycle and ensure that links are made between each stage. Learning can start with any stage or element. When starting with concrete experience, the information that serves as a basis for reflection is provided. Through reflections the information is assimilated to form abstract concepts. The concepts are used to develop new theories about the world. The theories are then tested. Through the testing of ideas, information is gathered again through experience, thereby starting the cycle again. This model of learning can be used in various types of education including vocational and general education (Cherry, 2014 [online]; Dochy, et al: 2011:54 and Tennant, 2006:87).

\section{Definition, Features and Importance of WBE to Students}

As indicated previously, SSACI was responsible for the introduction and popularization of WBE at FET colleges in South Africa. WBE is regarded as another approach to Work Integrated Learning (WIL), which refers to a short period of learning and experience (minimum five days) in a real world of work. It is an umbrella term for exposure and or practical experience for on-course students in the place of work not simulation centers. Simulations are part of FET college infrastructure for students to do practical work, which at some FET colleges are not used effectively. WBE practice does not in any way replace the use of simulation centers, but rather supplement what the simulation centers offer to the 
students. WBE is regarded as a term that was coined and popularized following the inception of FET Colleges sector. It is important to note that while WBE is encouraged for the NCV program students, it is not yet a requirement for students to graduate (SSACl, 2012:5; City \& Guilds, 2014 [online], Taylor, 2013:3-5).

The main feature of WBE is its flexibility. Contrary to the common practice, students are not placed for strictly prescribed period of months as is the case with learnerships, internships and other related programs. Although WBE encourages colleges to place students with well-established employers, it is not a must as it has been common practice to be placed with formal and accredited or registered companies. While it is encouraged that students engaged in WBE should be hands on or do authentic work not merely observe others at work, it is not a must that they should always do practical work. Unlike with other work integrated education models employers are not bound by any law to pay students. The WBE model urges the colleges to enter into agreements with employers. SSACI (2012:28) notes that it is important that agreements be captured in writing. They might be in the form of legally binding MoUs (Memorandums of Understanding). However, the absence of MoU does not in any way hinder the process of student placement.

It was indicated above that the function of the FET college is not limited to education and training in the classroom. The college should ensure that the students get exposure to the world of work. The following paragraphs focus on the importance of WBE to students:

Creation of networks: Sides and Mvrica (2012:55), while referring to networking of the interns, state that networking is one of the important learning opportunities. The authors further indicate that networking develops by knowing other people. While the learner develops networks with people of the same profession or area of study, it can go beyond and reach other members outside the profession. This is also applicable in WBE. In emphasizing the importance of WBE, SSACI (2012:5) states that as learners are placed with different employers, their social and professional linkages with labor market is widened thereby opening opportunities for employability after completion of studies.

Preparation for Employability: It is reported that in South Africa the youth unemployment rate is at an unprecedented level (Tshazibana: 2014:17). Tshazibana further states that "...chances of getting a foot in the door without experience is very slim...". This emphasizes the importance of WBE in preparing students for the world of work. Students acquire practical skills and become confident to enter the place of work. Also, as SSACI (2012:2) succinctly states, through the three years at college, employers trace the students and reduce costly recruitment processes when employing graduates afterwards. When students are at the workplace, employers get an opportunity to gauge the quality of the programs offered by the colleges. The students are also assessed with possible permanent employment opportunities (refer also Gert Sibande FET College, 2011: 13).

Deeper understanding of career and improved management of studies: At the workplace students are able to relate classroom activities with the workplace. This also helps the learner to develop more interest and the confidence improves. With improved confidence, the students get more focused on the studies in order to complete and enter the place of work. WBE increases students certification and throughput rate as motivated students with positive self-concept tend to perform better (SSACl, 2012:5-6).

Acquiring communication and interpersonal skills: The workplace is a place where learners meet people other than their classmates and lecturers. Relationships are formed. Learning also takes place through relationships (Sides and Mrvica, 2012: 20). By interacting with other people at the workplace, they are also provided with communication and other related life skills which are important when they enter the field of work after completion of studies (SSACl, 2012:5-6).

Keeping abreast of current technologies: At the colleges, students acquire practical experience in their workshops and simulation rooms. In the workplaces they are exposed to recent developments especially in technology which their workshops and simulation centers do not have. If their learning was restricted to the classroom, workshops and simulation centers, they would not be exposed to new technologies which they would meet soon after completion of studies.

Development of entrepreneurship skills: Not all the students study in order to be employees. Some would like to create jobs and become employers. Also, with the high rate of unemployment, students are encouraged to venture into business. At the place of work, students acquire practical experience and skills that will help them to venture in their own businesses and create jobs.

\section{Research Design and Methods}

The qualitative approach was used in this study. The researcher was a Workplace-Based Officer of the college. The Researcher Journal was used to write notes when the researcher was taking rounds of monitoring students at the different work places. Interviews with ten students were also conducted to collect data from the students studying at the two campuses of one college. 


\section{Research Findings and Discussions}

It was indicated above that when monitoring at the workplaces, the researcher held brief meetings with the employers to get feedback on the placement process. The Researcher Journal was used to keep notes. The researcher also conducted interviews with students. Research findings will therefore come from the Researcher Journal and interviews with students.

\subsection{Research findings from the Researcher Journal}

From the data collected by means of a Researcher Journal, the following were discovered:

Shortage of work experience places: In rural areas formal big businesses and industries are few. As the students' enrolment at the college increases, the students outnumber the employers. Moreover, businesses are dominated by small companies found mostly in the townships and villages, which some students disdain. In the study on apprenticeship Griffithis (2004:28) discovered that one of the problems encountered in the placement of students is shortage of employers. Although Griffithis in his writing was referring to shortage of work places for apprentice in Germany, as indicated previously, this is the case with rural areas of South Africa.

Inaccessible employers: It was discovered that accessibility in terms of distance is another challenge. Most of the students come from poor economic background. They stay in the villages and townships and do not have money for travelling to the employers which are situated in towns. Although grants have been created for WBE to incentives the students, this is still not enough to cater for their transport and meals.

Reluctant employers: Some employers who had accommodated the students indicated dissatisfaction with the placement process as they were not sure of the skills of students in the new NCV program. Literature indicates that "Placement with employers is only possible if employers are willing to host students" (SACCl, 2012:25). It is also reported that the inception of NCV programs was from the onset not welcomed by most of the employees. Resultantly employers were reluctant to accommodate the NCV students probably because the program was new (SSACl: 2012:2). Centre of Higher Education Transformation (CHET) in City Press (2014 [online) also noted that "FET colleges have a poor image with employers...." This has an impact on students placement and prospects of employment, as most companies claim that they do not know the $\mathrm{NC}(\mathrm{V})$ programs.

Maintenance of Partnership: Some employers were against maintaining long lasting relationship as they did not buy the idea of short periods during college holidays. They appeared to be used to the conventional placement according to months and years. And they would agree today only to decline when the placement period approaches. Moreover, some enter into partnership with the hope of gaining financially. If that does not happen, they exercise passivity until the relationship collapses.

\subsection{Research findings from interviews with students}

It was indicated above that students are placed with different employers during the holidays. During the period of placement when students are at their workplaces, the researcher together with some college staff members would take rounds of monitoring. During monitoring, it would be discovered that some students had either not reported or reported and disappeared. This happened especially at workplaces in the villages and townships. When the researcher informally tried to get motives for non-reporting and disappearance of students, some students attributed non-reporting and disappearance of students to negative perceptions towards SMMEs. This tendency compounded the problems such as shortage of employers and reluctant employers as indicated previously.

As indicated above, interviews were conducted with students. The researcher had a list of students who were placed with different employers. Some students refused to be interviewed on hearing the purpose of the interviews. The researcher ended up interviewing ten students who volunteered to be interviewed.

Two questions were asked and the findings from interviews were based on these questions:

- As a student, do you see any significance of being placed at SMMEs for experience?

- Why do some students dislike placement at SMMEs for experience?

\subsubsection{The significance of placement at SMMEs for experience}

Their responses on the significance of being placed at SMMEs were unitized in order for the units that belong together to be grouped into themes which served as research findings. The table below shows the units that emerged from students' 
responses.

Table 1: Responses of students on the significance of placement at SMMEs

\begin{tabular}{|ll|}
\hline$\bullet$ & More practical opportunities \\
\hline$\bullet$ & You gain confidence \\
\hline$\bullet$ & You are free to make mistakes \\
\hline$\bullet$ & You learn how to start your own business like them \\
\hline$\bullet$ & You cannot start learning from the top \\
\hline$\bullet$ & You learn different tools \\
\hline$\bullet$ & There are many customers in the township \\
\hline$\bullet$ & People who bring cars are many \\
\hline$\bullet$ & Mechanics appreciate your work \\
\hline$\bullet$ & You get the basics before you go to big companies \\
\hline$\bullet$ & They have time to teach you \\
\hline$\bullet$ & When you go to big companies you have confidence \\
\hline$\bullet$ & They remove fear \\
\hline$\bullet$ & They are open \\
\hline$\bullet$ & Big companies need people with experience \\
\hline$\bullet$ & At big companies you just sit and observe and do nothing \\
\hline$\bullet$ & When you later apply at big companies they take you \\
\hline$\bullet$ & You get foundation of what big companies need \\
\hline
\end{tabular}

The following themes /findings emerged on the significance of placement at SMMEs.

\subsubsection{More practical work opportunities}

The majority of students who participated in the interviews stated that at the SMMEs students are afforded more opportunities than at big businesses where they may sit and do nothing. This is ascribed to the fact that there are many customers who bring cars for repair and services in the townships and villages. The following are excerpts of interviews with some of the students:

"There are more practical work opportunities. If the cars need minor services, students are given opportunities to do minor services."

"In the townships or villages there are many customers who bring cars for repairs, so you get enough practical experience. Big companies sometimes need a person with previous experience to do practical work."

"You do lot of practical work because many people bring cars. At big companies they may say just sit and observe and do nothing."

\subsubsection{Acquiring the basics/ foundation and gaining confidence to face big companies}

Some students saw the significance of being placed at SMMEs as students get the basics of their practical experience while on the other side they gain confidence. Some big companies need prior practical experience. The basics and confidence help them to face work at big companies as some students put it:

\footnotetext{
"If you are given a car to service and you succeed you have confidence. At small businesses you are free to make mistakes. They correct you and give you another chance. You are given freedom to learn and know different tools and how they are used."
}

"When we are at small businesses we are free to ask questions and learning becomes interesting."

"They are open, so they remove fear. When you go to big companies you have confidence."

"You get basics before you go to big companies. They have time to teach you parts of the computer and how they work. You have opportunities for growth." 
"You are kept busy ....". They give the basics that the big companies need. It is good foundation."

"They give you the basics/foundation of what the big companies need. You cannot start at the top."

\subsubsection{Reasons students dislike placement at SMMEs}

The transcripts of students when asked why some students dislike placement at SMMEs were unitized as follows:

Table 2: Responses of students on aversion of placement at SMMEs

\begin{tabular}{|ll|}
\hline$\bullet$ & They are concerned about safety \\
\hline$\bullet$ & The companies are not registered \\
\hline$\bullet$ & They need money \\
\hline$\bullet$ & Some companies cannot write testimonials \\
\hline$\bullet$ & Testimonials at small companies are not recognized by big companies \\
\hline$\bullet$ & They need more income \\
\hline - & White-owned companies pay more money \\
\hline - & Big companies are better equipped \\
\hline - & Services are not enough at small companies \\
\hline & The standard is low \\
\hline
\end{tabular}

The following themes/findings emerged from interviews units with students on reasons some students dislike placement with SMMEs:

\subsubsection{Concern about safety and security and registration of employers}

While they see the significance of placement with small companies, some students have reservations. They regard standards as being low mainly because some SMMEs are not registered and not accredited. Unregistered companies often do not comply with safety and security rules. Some lack the necessary equipment and cannot write testimonials for students. When interviewed some students expressed themselves as follows:

"Some students are concerned about safety and security. They think they are not protected enough because most of the businesses do not meet safety standards".

"Some companies are not registered. If you are called for job interview and they see a testimonial from unregistered company, they may not consider you for appointment."

"Some small businesses do not give testimonials. Students think that if you get practical experience from small businesses and you apply for job in town they will not take you seriously."

\subsubsection{Inadequate financial incentives}

Expressed more often by participants, was the issue of money. Participants think that money plays a role in some students not being in favour of placement at SMMEs. Some students might be thinking that the bigger the company, the more money it has. They might also be thinking that whites who own big companies have money to pay them than small companies owned by black people. The following are some of their narratives:

"They need more income. They think at big companies they will get more and forget what they should learn. They say big companies have better equipment than small businesses."

"They need money. They think companies owned by whites will pay better stipends."

\subsubsection{Laziness and racial attitude}

Although mere laziness was regarded by some students as the reason students dislike to be placed at the SMMEs, more controversial was the issue of race which was expressed by others students. The issue of race could be traced back to 
the pre-democracy period in South Africa when people where divided on racial lines. The following are interviews excerpts from some of the students:

"Some students are lazy. At small businesses we work very hard. At big businesses they just sleep."

"I think they are just lazy. At small business the work experience is hands on. They work very hard. Some just undermine the owners. You know that old mentality. Most of the small businesses are owned by blacks. So anything black is downgraded. They might be thinking that at big companies owned by whites they will get more money."

Upon examination of the findings from the Researcher Journal and findings from interviews with students, the researcher deduced that the students placement at workplaces in general and at SMMEs in particular is significant to students. However, two things are notable which needs attention, namely:

- Inadequate advocacy and education of employers in general and SMMEs in particular about WBE.

- The students proper understanding of what the businesses in general and in particular SMMES can offer in relation to the curriculum.

Therefore the paragraphs below focus on recommended strategies to educate employers and change the rural FET college students' perception regarding SMMEs for WBE in order to increase the rate of students' placement with employers.

\section{Recommendations}

It was indicated above that students do not acquire only practical skills at the workplace. The key factor as literature indicates (Taylor, 2013:4) in the success of WBE is how WBE links the curriculum with industry needs. Also, realizing that in most cases students believe that any workplace learning without practical hands-on experience is not highly regarded while linking the curriculum with industry activities is still a challenge and the employer still struggle to understand the NCV programs, the following are recommended:

\subsection{Empowering businesses and SMMEs in particular through training}

It was indicated above that some employers appear to still lack understanding of the new NCV program. In the interviews with students the concerns that come often in the interviews with students are safety at work, registration and accreditation, testimonial writing and stipends. The issue of stipends is partially addressed by the department and the colleges through NSF (National Skills Fund as stated above. Although some concerns are genuine, they cannot hinder students placement as WBE has a variety of benefits. However, these concerns cannot be ignored. Two ways are recommended to make WBE understood and empower business to address the concerns.

The first one is the establishment of College-Small Business Employer Forum, which should be spearheaded by the college. It is a fact that some of these employers do not understand this NCV program as it is new and different from the old NATED program. The forum will serve as platform for intensive advocacy and training. As literature states (Taylor, 2013:4), in WBE implementation it is important to consider what students should do at the workplaces, what is required of the employer and records should be completed to serve as evidence, it will be a platform where small businesses are given lessons about FET colleges in general and in particular clarified about WBE and its operations. This will include the colleges' expectations of the employers (what employer should do, the formal agreements with employers, supervision and completion of the necessary documents).

The second one pertains to training of the small businesses. The FET colleges are well-resourced in terms of infrastructure. They have expertise in the field of business administration at both their central (corporate) offices and campuses. Colleges have been advised not to work alone in the implementation of the NCV programme thereby implementing the government slogan of "together we can do more". They have been tasked to forge links with partners such as government departments, Sector Education and Training Authority (SETAS), industry, business and education institutions in order to be responsive to the job market. The students concerns such as safety at work are genuine and legitimate. Students (compare Labour Relations Act (LRA), Occupational Health and Safety Act (OHSA) and Occupational Injuries and Diseases Act (COIDA) although attached to the employer not as permanent workers, are protected and should also abide by these laws. Some employers deliberately contravene the laws by not applying any of the prescribed safety measures, which is to the detriment of the student. On the flip side, the students indemnity forms that some colleges claim to use, are not trusted by the employers. In order to address these issues the colleges can 
collaborate with partners such as the SETAs to offer relevant training to small businesses in matters pertaining especially to safety and security at work, while not ignoring registration of companies and accreditations of service providers. One is of the opinion that as much as the colleges need the services of the small businesses, the small businesses also need the services of the colleges. Also, while attempting to bring small businesses to the level where they could be acceptable to the students, the college would be rendering one of its important task, that of social responsibility.

\subsection{Identifying the links between the Curriculum Program and industry activities}

The lecturer in a particular program should identify the links especially of the core subjects with the WBE activities of a particular employer. The students should be made aware of the links which may serve also as the outcomes to be achieved during placement with the employer. The researcher used Hospitality program as an example.

As stated previously, catering is one of the common businesses in the semi-urban and rural areas of South Africa today. There are unregistered and mostly registered companies. Some companies might not be registered because the owner does not know the procedures or lack funding. Catering companies work in funerals, parties, rallies, conferences, weddings, etc. Usually they do not operate with permanent staff, which is an advantage for college students to be placed with. The table below depicts the relationship between the activities of small business and the college curriculum in Hospitality and can be used as an example by lecturers.

Table 5: College curriculum items with corresponding workplace activities.

\begin{tabular}{|c|l|l|}
\hline No & \multicolumn{1}{|c|}{ Curriculum item } & \multicolumn{1}{|c|}{ Workplace activity with small business } \\
\hline 1 & Customer care & $\begin{array}{l}\text { Students interact with a variety of customers, the mourners in funerals, the jubilant in } \\
\text { weddings and graduation ceremonies and the emotional in political rallies. They observe } \\
\text { their behavior and learn to serve and deal with the different types of customers. }\end{array}$ \\
\hline 2 & Food preparation & $\begin{array}{l}\text { Students are exposed to different ways of preparing food learnt in class and have hands on } \\
\text { experience as they cook. }\end{array}$ \\
\hline 3 & Table setting & $\begin{array}{l}\text { Different types of settings are experienced practically, e.g the one line table, the round } \\
\text { tables, the two line table and table decoration. }\end{array}$ \\
\hline 4 & Safety \& hygiene & $\begin{array}{l}\text { In all functions, be it political rally, funeral and conference, the servant will follow required } \\
\text { etiquette and code of ethics such as "doek" on the head, aprons and provision of water for } \\
\text { customers to wash. }\end{array}$ \\
\hline 5 & Menu planning & $\begin{array}{l}\text { Students see how the different types of menu learnt in class are planned to suit types of } \\
\text { customers and pockets of people whose service is done. }\end{array}$ \\
\hline 7 & Identification of drink items & $\begin{array}{l}\text { Students observe and practically serve guests in traditional funeral or in rallies in queues as } \\
\text { compared to municipality council meetings where there is self-service and guests are } \\
\text { served around table }\end{array}$ \\
\hline 8 & $\begin{array}{l}\text { Students learn that drink items in modern funeral of after-party will be different from drinking } \\
\text { items of big jars of diluted juice which is typical of traditional funeral }\end{array}$ \\
\hline 9 & $\begin{array}{l}\text { Use of specific equipment } \\
\text { and utensils }\end{array}$ & $\begin{array}{l}\text { Packing before use and washing and packing after use is observed and done by students } \\
\text { In a traditional funeral big three-legged ports will be used on a wooden fire, while big } \\
\text { saucepans will be used on electrical or gas stoves in modern funerals }\end{array}$ \\
\hline 10 & $\begin{array}{l}\text { Correct usage of cutlery } \\
\text { and crockery }\end{array}$ & $\begin{array}{l}\text { Type of cutlery used for political executives, will be different from the one used for mass of } \\
\text { people in the funeral or church conference. Students observe how these are used and also } \\
\text { have hands-on experience in using them. }\end{array}$ \\
\hline
\end{tabular}

\section{Conclusion}

The FET Colleges in South Africa were established as one of the strategies of tackling skill shortages, job creation and economic growth. This translates into employability. Since its establishment, the enrolments at the colleges have been increasing. The success indicator of the college sector is, however, not enrolment but employability. Students' ability to access employment is limited by lack of exposure to the place of work, the shortage of workplaces especially in the rural areas, which is compounded by students' aversion to placement at SMMEs. The purpose of this research was to explore the perception of students at a rural FET college regarding SMMEs for work-placement. It is hoped that the lessons drawn from this research will help other colleges to improve the placement rate. 


\section{References}

Cherryl,K n.d. David Kolb's theory of learning (in About.com Psychology) http://Psychology.about.com/od/educationalPsychology/a/ experiential-learning.htm. (Accessed 12/06/2014).

Büdke, C and Roopnarian. In City and Guilds. 2012. Workplace-Based Experience for South Africa's young people. http://www.skills development.org/knowledge-portal/e-zine/summer-2012/workplace (Accessed 24/02/2014).

City Press. 2012. Young, jobless and desperate-will FET colleges fix our future? 23 June, 2012) http://www.city press.co.za/news/youngjobless-abd-desperate-will-fet-colleges-fix-ou...(Accessed 2014/02/13).

Cooney,R and Stuart,M (edit). 2012. Trade Unions and Workplace Training. Issues and International Perspectives. London: Routledge .

Department of Education (DoE). 2007. FET Colleges. Institutions of First Choice. Pretoria: Rainbow SA.

Department of Higher Education and training (DHET) n.d. Khetha. Make the right choice. Decide your future. Pretoria: DHET.

Department of Higher Education and Training (DHET). 2013. Delivery Agreement 2. Pretoria: DHET.

Dochy,F; Gijbels,D; Segers,M and Van Den Bossche,P. 2011. Theories of learning for the workplace. Building blocks for training and professional development programs. London: Routledge.

Gert Sibande FET College. 2011. Annual report 2011. Standerton RSA: Gert Sibande FET College.

Griffithis, T, \& Guile, D.2004. Learning through work experience for the knowledge economy. Issues for educational research and policy. Luxembourg: European Centre for the Development of Vocational Training.

Mopani South East FET College. 2012. Workplace Exposure . In the Mopani Dispatch. Issue no. I July-December 2012.

Sides,C.H and Mrvica,A. 2007. Internships. Theory and Practice. New York: Baywood Publising Company,Inc.

SSACI. 2012. Providing Workplace-Based Experience (WBE) for FET College Students. A Manual for College Managers and Lecturers. Houghton RSA: SSACl.

Taylor, V. 2013. Workplace-Based Experience (WBE). For FET college students: Providing WBE as an assessed component of the NC(V). Paper for the National Skills Conference.

Tennant, 2006. Psychology and adult learning. Third edition. New York: Routledge.

Tshazibana, F. 2012, January 8. Give youth foot in workplace door. Sowetan,p17. 